\title{
Historiefag og historiepolitik
}

Termen 'historiepolitik' er ganske ny i en dansk sammenhæng. Skrives ordet $\mathrm{i}$ titelfeltet på bibliotek.dk, er der kun 3 hits, hvoraf det ene er en ph.d. afhandling fra 2009. Går vi videre til google.com, er der små 500 hits, hvoraf flere er svenske udgivelser. Indtaster vi derimod den tyske term 'Geschichtspolitik', stiller sagen sig anderledes; her er der 52.000 hits, og i den tyske udgave af Wikipedia er det et selvstændigt opslagsord. Jeg vil derfor kort gøre rede for termens tyske ophav og for, hvordan den bruges i en tysk sammenhæng.

At termen normalt ikke bruges i en dansk sammenhæng, betyder ikke, at det sagforhold, begrebet refererer til, er fraværende. Der findes mangfoldige eksempler på dansk historiepolitik; her vil jeg dog alene se på, hvordan danske faghistorikere forholder sig hertil. Den styrende problemstilling kan formuleres som følger: betragter faghistorikere det som legitimt at bedrive historiepolitik som led i deres faglige virksomhed? Og i lyset heraf rundes der af med overvejelser over historiepolitik som faglig udfordring.

\section{Ophav i en tysk erfaringsverden}

Første gang jeg bemærkede brugen af det nye begreb var i forbindelse med læsningen af Edgar Wolfrums disputats Geschichtspolitik in der Bundesrepublik Deutschland. Der Weg zur bundesrepublikanischen Erinnerung 1948-1990 (1999), hvor det fremgår, at det til dels skal fungere som et synonym for eller oversættelse af er andet tysk nøglebegreb, nemlig 'Vergangenheitsbewältigung' (dvs. en aktiv fortidsbearbejdning).

De allierede stillede efter anden verdenskrig krav om, at de(n) tyske befolkning(er) skulle gøre op med nazitiden, og det har efterfølgende været muligt at sammenligne, hvordan den udfordring blev håndteret i Vesttyskland, Østtyskland og Østrig, men jeg nøjes her med at se på den vesttyske håndtering af sagen. De vestlige besættelsesmagter satte sig fx. for at gennemføre en politisk genopdragelse (re-education) af befolkningen således, at vesttyskerne fremover blev tilhængere af 
et vestligt repræsentativt demokrati. Det var i forbindelse hermed, at den første vesttyske præsident, Theodor Heuss (1884-1963), brugte begrebet 'Vergangenheitsbewältigung' - dvs. at der var behov for at bearbejde og overvinde, hvad vesttyskerne havde bragt med sig fra nazitiden.

Der indgår to vigtige antagelser i en sådan tankegang. For det første at det fortidige kan leve videre i og dermed kan være med til at forme et nutidigt liv (dvs. er del af en kulturarv), og for det andet at denne kulturarv kan være en så integreret del af folks identiteter, at de ikke vil kunne lægge den bag sig uden en energisk og målrettet indsats. Når der tales om behovet for en aktiv fortidsbearbejdning, drejer det sig følgeligt om en særdeles ømfindtlig historie - bl.a. fordi der til den vil være knyttet følelser af skyld og skam, og den vil vedrøre etiske dilemmaer om forpligtelse og ansvar.

Siden 1950erne har spørgsmålet om en 'Vergangenheitsbewältigung' udgjort et tilbagevendende tema i vesttysk politik (Fulbrook 1999), og der findes i dag et Lexikon der 'Vergangenheitsbewältigung' in Deutschland. Debatten- unde Diskursgeschichte des Nationalsozialismus nach 1945 (2007). Mange debatter fandt sted i en bred politisk offentlighed, bl.a. ved rejsning af mindesmærker, men der er også de debatter, hvor fagfolk har stået i centrum. En af de mere kendte var den såkaldte 'Historikerstreit' i 1986 og 1987. Betegnelsen er dog ikke helt velvalgt, idet flere af hovedaktørerne (fx Ernst Nolte (f.1923) og Jürgen Habermas (f.1929)) er filosoffer snarere end faghistorikere. Til gengæld drejede det sig om en meget heftig og tilspidset strid om vesttyskeres fortidsfortolkninger og deres brug af dem.

Striden blev udløst, da Nolte i sommeren 1986 fik foredraget "Vergangenheit, der nicht vergehen will" trykt i det konservative dagblad Frankfurter Allgemeine Zeitung. Tyskernes nazistiske fortid var den fortid, der endnu ikke var skrinlagt, men det søgte Nolte at gøre ved at indplacere nazisternes massemord i dets rette sammenhæng. Han søgte således at forklare det som en reaktion på det massemord, bolsjevikkernes havde begået under Stalin:

Begik nazisterne eller Hitler måske en 'asiatisk' [mis]gerning alene, fordi de og deres ligesindede så sig selv som mulige ofre for en 'asiatisk' [mis]gerning? Gik øhavet GULag ikke forud for Auschwitz? Var bolsjevikkernes klassemord ikke den logiske og faktiske forudsætning for nazisternes racemord? 
[...] Gik de grundlæggende årsager til Auschwitz ikke tilbage til en fortid, der ikke lod sig skrinlægge? (Augstein 1987: 45).

Habermas var den første til at tage Noltes udfordring op. Det skete i det liberale dagblad Die Zeit, hvor han betegnede Noltes intervention som en 'Schadenabwicklung' - dvs. forsøg på at afvikle den gældsbyrde, tyskerne havde pådraget sig som følge af nazisternes folkemord, og han advarede samtidigt mod national-konservative forsøg på at relativere og dermed negligere denne del af tyskernes fortid. Herefter rullede historikerstriden for fuld udblæsning i mere end et år.

Indførelsen af begrebet 'Geschichtspolitik' forstås formentlig bedst som forsøg på at almengøre de indsigter, der har ligget til grund for forestillingen om en 'Vergangenheitsbewältigung' (dvs. aktiv fortidsbearbejdning). Edgar Wolfrum definerer i førnævnte værk begrebet på følgende måde:

Historiepolitik er et felt for handling og politik, hvor forskellige aktører bearbejder og søger politisk at udnytte det fortidige i lyset af deres specifikke interesser (Wolfrum 1999: 25).

Wolfrum peger i den forbindelse på, at historiepolitik ikke er noget, der er forbeholdt faghistorikere, og at en faglig historieforskning som regel kun spiller en mindre rolle i de historiepolitiske udspil, der tages i et samfund. Han beskriver opfølgende historiepolitik som "den aktivt førte politik ved hjælp af fortidsfortolkninger" og "et situationsbunden og foranderligt våben, som politikere uvægerligt gør brug af"'(Wolfrum 1999: 27 og 29).

\section{Ved indgangen til 2000-tallet}

Jeg er helt på linje med Wolfrum, når han fremhæver, at historiepolitik ikke er noget, der er forbeholdt fagfolk, og derfor understreger, at historiepolitik indgår som et integreret element i de konkurrerende politiske udspil, der udgør dagens orden i et demokrati. Der kan dog stadigværk være grund til at se på, hvordan faghistorikere forholder sig til historiepolitik, blot det erindres, at deres indsats ikke må tilskrives en alt for vidtgående indflydelse. I det følgende ser jeg på, hvordan fagfolk har placeret sig på den historiepolitiske scene, når det drejer sig om særdeles ømfindtlige historier.

I februar 2000 fik den islandske historiker Vilhjálmur Örn Vilhjálms- 
son (f.1960) trykt en kronik om "Den største myte" i Berlingske Tidende, og heri pegede han på, at mindst 21 statsløse jøder af de danske myndigheder var blevet udvist fra Danmark til Tyskland under besættelsen, og flere af dem endte deres liv i de nazistiske udryddelseslejre - altså et helt andet billede af danskerne end det, der tager afsæt i den glorværdige redningsaktion af oktober 1943.

Afsløringen vakte så megen opsigt, at den daværende statsminister Poul Nyrup Rasmussen (f.1943) straks iværksatte en undersøgelse af sagen. I efteråret $2000 \mathrm{blev}$ der nedsat en forskergruppe til at undersøge, hvordan danske myndigheder havde behandlet (jødiske) flygtninge før og under besættelsen, og i den indgik bl.a. de to danske faghistorikere Hans Kirchhoff (f.1933) og Cecilie Banke (f.1965). Resultaterne af gruppens undersøgelser blev offentliggjort i 2005 og 2006.

Der var i november 2001 sket et regeringsskifte, og det var derfor den nye statsminister Anders Fogh Rasmussen (f.1953), der blev frontfiguren, da 60-året for henholdsvis Augustoprøret og Danmarks befrielse skulle markeres i august 2003 og i foråret 2005. Han brugte jubilæerne til at fremsætte særdeles profilerede historiepolitiske udmeldinger om bl.a. samarbejdspolitikken under besættelsen. Det udløste en større strid blandt danske faghistorikere, idet der både var dem, der i skarpe vendinger angreb Fogh Rasmussens intervention, men også dem, der forsvarede den. Blandt hans mest ihærdige kritikere var Hans Kirchhoff, hvorimod Cecilie Banke hørte til dem, der bakkede Fogh Rasmussen op (Jensen 2010).

Og nu til den forste historiepolitiske strid. Fogh Rasmussen gjorde, hvad politikere plejer at gøre ved et jubilæum, nemlig at bruge det til at oparbejde en historiebevidsthed - dvs. etablere en betydningsbærende sammenhæng mellem noget fortidigt, nutidigt og fremtidigt. Han brugte erfaringerne fra besættelsestiden til at oparbejde en fortidskritisk historiebevidsthed - eller med hans egne ord: "vi alle har pligt til at se kritisk på historien - for at lære af den", idet "vi kan gøre vort yderste til, at den ikke gentager sig" (Fogh Rasmussen 2005).

Fogh Rasmussens udmelding var markant og profileret; han beskrev datidens Danmark som "et lydigt redskab" og den førte samarbejdspolitik som "en aktiv tilpasningspolitik" i forhold til tyskerne. Når han pegede på, at "det officielle Danmark" dengang havde gjort sig skyld i "et politisk og moralsk svigt"(Fogh Rasmussen 2005), var der ikke kun tale om en kritisk vurdering af bestemte fortidige forhold. Sigtet var at drage en politisk lære heraf, og den, han drog, var, at Danmark burde forfølge en 
aktivistisk udenrigspolitik.

[...] lærdommen fra d. 29. august 1943 gælder stadig. Det handler om at tage stilling og turde handle derefter - også selvom det ikke er den mest behagelige beslutning. Det gjorde Danmark under konflikterne på Balkan i 1990erne, og vi gjorde det i kampen mod terrorister i Afghanistan i 2002 og i forbindelse med den netop overståede krig mod Saddam Husseins tyranniske regime i Irak (Fogh Rasmussen 2003).

Fogh Rasmussens historiepolitiske udmelding blev straks imødegået af flere faghistorikere; fx brugte besættelsestidshistorikeren Hans Kirchhoff sin fratrædelsesforelæsning ved Københavns Universitet i oktober 2003 til at lancere et frontalt angreb på hans bruge af historien. Kirchhoff betragtede ikke kun Fogh Rasmussens fortidsbrug som et forsøg på "at moralisere i bagklogskabens klare lys", han gik videre og kaldte det for et regelret "misbrug af historien" - ja, endog et forsøg på at "dæmonisere historien". Og Fogh Rasmussens faux pas blev forklaret som en følge af hans uvidenhed og hang til moraliseren (Kirchhoff 2003a\&b \& 2005).

Ikke alle danske faghistorikere stillede sig kritisk afvisende til Fogh Rasmussens indgribende historiebrug. En af dem, der kom ham til undsætning, var Cecilie Banke, der formulerede det på denne måde:

Jeg synes han gjorde ret $\mathrm{i}$ at sætte [besættelsestidens moralske spørgsmål] på dagsordenen, så vi kan få en revurdering af valgene ud fra vor tids moral. Vi skal jo genfortolke historien ud fra de spørgsmål, vi stiller til os selv og historien (Blüdnikow 2005).

Når Banke tænkte anderledes end Kirchhoff, er en del af forklaringen, at hun tilhører et yngre kuld af faghistorikere, og når hun ikke afviste, hvad Kirchhoff betragtede som Fogh Rasmussens nymoralisme, var det, fordi hun ville basere sin egen historieforskning på følgende moralske grundantagelse:

Du har selv et ansvar, og det er ligegyldigt, om du begår stikkerdrab eller er palæstinensisk selvmordsbomber. Det er den moral, der ligger bag det her opgør med historien (Brask Rasmussen 2005).

Samtidigt med at Kirchhoff og Banke tog del i den ophedede debat om Fogh Rasmussens brug/misbrug af besættelsestiden, indgik de i det nævnte forskningsprojekt om dansk flygtningepolitik før og under besættelsen. Det er derfor relevant at undersøge, om forskellen mellem Kirchhoff og Banke også viste sig i deres historiefaglige fremstillinger. De er 
enige om, at historierne om dansk flygtningepolitik udgør en særdeles ømfindtlig historie, men måden, hvorpå de forholder sig til de ømme tæer, er ret forskellig.

Kirchhoff kalder sin bog Et menneske uden pas er ikeke noget menneske. Danmark i den internationale flygtningepolitik 1933-1939 (2005) og lægger ud med at tage afstand fra den "overfladiske moralisme", som har præget meget forskning om datidens flygtningepolitik. Han stiller sig derfor afvisende til den opfattelse, at man i 1930erne havde været "bystanders, dvs. dem der så til fra sidelinjen, mens tyskeren forfulgte og myrdede løs”.

Kirchhoff vil med sin bog at give et nøgternt og afbalanceret billede af, hvordan dansk flygtningepolitik i 1930erne tog sig ud i et komparativt perspektiv, og bogen er et fint eksempel på en oplysende historiebrug, hvor hovedkonklusionen er, at man i 1930erne ikke kunne have handlet meget anderledes, end man gjorde. Kirchhoff vil følgelig ikke medtænke Holocaust ved behandlingen af 1930ernes flygtningepolitik.

Kirchhoff lader dog sit humane og moralske engagement skinne igennem på en indirekte måde. Det fremgår fx. af hans valg af bogens titel: Et menneske uden pas er ikeke noget menneske - et citat af flygtningevennen Ellen Hørup, der signalerer en moralsk stillingtagen til behandlingen af statsløse flygtninge. Det fremgår også i hans forsideillustration: et billede af en jødisk pige, der sidder alene med sin dukke på en trappeopgang $\mathrm{i}$ London - et billede der givetvis vil vække empati og sympati hos bogens brugere. Så trods det at Kirchhoff i forste række satser på en oplysende historiebrug, fremstår hans bog samtidigt som et noget indpakket historiepolitisk udspil.

Banke kalder sin bog Demokratiets skyggeside. Flygtninge og menneskerettigheder $i$ Danmark for Holocaust (2005) - i sig selv en meget sigende titel, og modsat Kirchhoff føler hun sig foranlediget til at medtænke Holocaust fra første færd. Bogens afsæt er den personlige anfægtelse, hun fik ved at besøge Auschwitz i september 2000 ved opstarten af nævnte forskningsprojekt:

I vores samlede europæiske bevidsthed står Holocaust [...] som den gåde, vi endnu ikke har løst, og som vi er nødt til at prøve på at forstå. Det er her, at denne bog begynder. I Holocaust som et europæisk traume, vi først nu kan tilnærme os og gøre til en del af den fælles historie (Banke 2005:11).

Bankes bog er et moralsk-politisk forsøg på at konfrontere sig med Holocaust som del også af en dansk kulturarv. Analysen centrerer sig der- 
for om to problemstillinger. Den første er: hvad var det i 1930erne, der gjorde, at danskere ikke udviste medmenneskelighed over for folk i nød? Det forklares med, at den etnisk-nationale forståelse af folkefællesskabet lagde op til en ekskluderende tolkning af både demokrati og velfærdsstat. Her findes altså forklaringen på bogens titel. Den anden er: ville en mere ihærdig folkelig protest have gjort en forskel? Her kan Banke kun finde frem til enkelte eksempler, hvor folkelige protester førte til lempelser af den førte flygtningepolitik.

Banke kalder sin konklusion "Upstanders and bystanders", og til forskel fra Kirchhoff mener hun, at der var ganske mange 'bystanders' i 1930ernes og 1940ernes Danmark, men der fandtes også enkelte 'upstanders' - dvs. "folk, som i menneskerettighedernes og humanismens navn protesterer mod forfølgelser”. Og hvor Kirchhoff fremhæver, at man i 1930erne ikke kunne gøre noget afgørende for at hjælpe de mange flygtninge, dér søger Banke at dokumentere, at flertallet ikke ville gøre noget seriøst ved sagen. Så også i deres faglige fremstillinger er der markante forskelle mellem Kirchhoff og Banke, når de skal omgås et så ømfindtligt emne som dansk flygtningepolitik for og under besættelsen.

\section{Ved indgangen til 1900-tallet}

Danske faghistorikere forholder sig - som det fremgår - forskelligt til historiepolitik ved indgangen til 2000-tallet. Er dette noget nyt, eller har der også tidligere været en skillelinje inden for historiefaget? For at belyse det vil jeg sammenligne, hvordan to historikere fra den radikale historikertradition tænkte herom ved indgangen til 1900-tallet, og anledningen vil igen være en særdeles ømfindtlig historie, nemlig indplaceringen af nederlaget i 1864 i en historiepolitisk sammenhæng. Det vil dreje sig om Kristian Erslev (1852-1930) og hans elev P. Munch (1870-1948).

Når der skal gives en karakteristik af, hvordan radikale faghistorikere tænkte om historiepolitik, er det oplagt at starte - ikke med Erslev selv - men med hans elev. P. Munch var ikke alene forfatter af historiske fagbøger og undervisningsbøger, men også en prominent politiker. Han var medstifter af det Radikale Venstre i 1905, repræsenterede partiet i Folketinget fra 1909-1945, beklædte flere ministerposter og var udenrigsminister i den af Th. Stauning leddede socialdemokratisk-radikale regering fra 1929 til 1940. Hvordan så Munch på forholdet mellem historievidenskab og politik? 
Radikale akademikere med tilknytning til dagbladet Politiken havde fra starten i 1882 været aktive i Studentersamfundet i et forsøg på at skabe en reformbevægelse omkring København. Da Studentersamfundet fejrede sin 25-årsdag i 1907, blev der udsendt et jubilæumsskrift, og heri havde Munch et bidrag om "Studentersamfundets Fremtidsopgaver". Han indledte med at pege på, at "Studentersamfundets Tilværelse har fra dets første Dag været knyttet til Radikalismen", og forklarede derefter, hvordan det hang sammen:

Der er et Væsensfællesskab mellem Videnskabens Arbejdsmaade og Radikalismens Samfundssyn.[...] Videnskabens forudsætningsløse Forsken, overført til Samfundet, fører følgestrengt til den Radikalisme, der kræver Retfærdigheden fyldestgjort uden Hensyn til alle de hævdvundne Rettigheder, der stiller hindrende i Vejen (Munch 1907: 14-15).

Videnskab og politik var for Munch to sider af samme sag, men kun for så vidt som at politikere var så fremsynede, at de indrettede deres politik i overensstemmelse med, hvad videnskaberne var nået frem til. En sådan tankegang havde rødder $\mathrm{i}$ en gammelpositivistisk tænkemåde: erkendelsesfremskridt frembragt af de positive (dvs. empiriske) videnskaber skulle fungere som løftestang for politiske og sociale fremskridt. Den var følgelig baseret på en normativ videnskabsforståelse, og den implicerede, at den politik, som fx Munchs politiske modstandere - Højre og Frikonservative - førte, med rette kunne betegnes som uvidenskabelig.

Året efter - i 1908 - opfordrede Munch sin lærer Erslev til at skrive en belærende artikel om 1864 - altså hvad der dengang fortsat udgjorde et af de store traumer i dansk politik. Når han fandt på at gøre det, var det, fordi han antog, at Erslev delte hans opfattelse af forholdet mellem videnskab og politik, og det havde han god grund til at antage. Da Erslev i 1906 lod sig opstille som folketingskandidat for det Radikale Venstre, havde han offentligt erklæret, at hans faglige virke skete med afsæt $\mathrm{i}$ dette partis program (Manniche 1981: 315). Munch må derfor være blevet noget overrasket, da han modtog Erslevs tilbagemelding:

[...] når De mener, at jeg skal skrive den [artikel om 1864], så overfører De på mig Deres egenskaber og Deres gerning. Det ville, som De siger, være historien anvendt på politikken, men jeg er nu engang langt mere historiker end politiker. [...] og jeg føler mig ikke kaldet til politisk virksomhed af nogen art. Og så drage politisk lære ud fra et område, hvorom mine kundskaber 
ikke går ud over det ganske almindelige, nej, det må De ikke forlange af mig (Sjøqvist 1976: 64-65).

Da Munch skrev til Erslev i 1908, var han ikke klar over, at denne var i færd med at lægge sin hidtidige gammelpositivistiske videnskabsopfattelse bag sig. Det blev først åbenbart i 1911, da Erslev udgav tre nye skrifter: (i) Historisk Teknik, (ii) Historieskrivning og (iii) rektortalen Vort Slagtleds Arbejde $i$ dansk Historie. Erslevs 1911-skrifter er komplekse og er præget af flere indre modsigelser (Jensen 2009b), og her vil især en af disse modsigelser være af særlig interesse. Erslev var helt på det rene med, at fortidsfortolkninger spiller en vigtig rolle i samtidens politik. I Historieskrivning (1911) blev det - i et kapitel om "Historiens Nytte" - sagt på denne måde:

Vi danske behøver [...] ikke at gaa uden for vore egne Grænser for at erkende, hvorledes Historieskrivning paavirker Nutidslivet. Hvor meget har danske Historikere ikke udrettet [i 1830erne og 1840erne] for at vække Forstaaelsen af, hvad vor folkelige Ejendommelighed betyder, og hvorledes den skal styrkes, ja selve vort Program mod den indtrængte Tyskhed, Ejdergrænsen, Slesvigs tusindaarige Danskhed, er jo formet eller i alt Fald knæsat af dansk Historieskrivning, hvad der baade er dens Ære og dens tunge Ansvar. [...] Om Historieskrivningens praktiske Indvirkning i hvert enkelt Tilfælde har været til Gavn eller Skade, kan man tvistes om, men at denne Virkning stadig findes, det kan ingen nægte, og der er sikkert ikke Grund til at tro, at det i Fremtiden vil stille sig anderledes (Erslev 1937: 253).

I lyset heraf kunne det forekomme oplagt at drage den følgeslutning, at det vil være et uomgængeligt vilkår, at faghistorikere bedriver historiepolitik. Men Erslev drog ikke den slutning. Han valgte i stedet at skelne mellem historieforskning (=> videnskab) på den ene side og historieskrivning (=> ikke-videnskab) på den anden. Når faghistorikere var historieskrivere, ville de uden tvivl påvirke folks tilhørs- og loyalitetsfølelser og tog dermed del i en indgribende og identitetsdannende fortidsbrug. Men når de optrådte som historieforskere skulle de afholde sig herfra. Som fagfolk måtte de alene satse på en oplysende fortidsbrug. Eller sagt med de ord, han selv brugte i rektortalen: "til først og sidst at søge og udtale den nøgne og usminkede Sandhed" - altså servere "en bedsk Lægedrik" for det danske folk (Erslev 1937: 219).

Erslev betragtes som grundlæggeren af moderne dansk historievidenskab, og måden, hvorpå hans tanker blev forvaltet, kom til at præge dansk faghistorie. Arven efter Erslev avlede således en dybtfølte ambivalens hos mange faghistorikere, når det drejer sig om det at engagere sig $\mathrm{i}$ 
historiepolitik. En fin og tilspidset formulering af et sådant tvesind findes hos Povl Engelstoft (1876-1961), en anden af Erslevs elever. Han havde fået i opdrag at præsentere sit fag i samleværket Danmarks Kultur ved Aar 1940 (1941-1943,) og han indledte her på denne måde:

Det gælder Historie mere end de fleste andre Videnskaber, at den har et Dobbeltansigt. Indadtil har den blikket ufravendt rettet mod Sandheden, Erkendelsen, den nøjeseende og retfærdige Forstaaelse af, hvad der egentig er sket. Den, der tjener Klio, 'Musen med den alvorlige Pande', maa hærde sit Sind mod Lidenskab og Frygt [...]. Han har kun én Herre, og det er Erkendelsen. Men udadtil - ingen Videnskab er som Historien blevet taget i det levende Livs Tjeneste. De Resultater, der er Frugten af Videnskabens Cellearbejde, er blevet omformet til Partiprogrammer, er skrevet paa Faner, der vajede over marcherende Masser, har tændt flammende Lyn for et Folk og har sænket det ned i Mørke. I en Nations gladeste og sorteste Timer har Historien rakt den sin Haand til Jubel, til Kamp, til Trøst. Derfor er Historieforskningen og Historieskrivningen en stor og betroet og farlig Gerning (Engelstoft 1943: 155).

Det er denne meget tvetydige faglige arv, som danske faghistorikere har skullet forvalte siden begyndelsen af 1900-tallet.

\section{Historiefag og historiepolitik}

Dansk faghistorie er ikke nogen homogen eller enstrenget tradition, når det gælder besvarelsen af spørgsmålet om, hvordan fagfolk bør forholde sig til det at bedrive historiepolitik. Der kan - idealtypisk - udskilles tre konkurrerende positioner:

1. historiefaget er også en normativ og partisk videnskab og kan som sådan bruges til at legitimere en bestemt politik (P. Munch).

2. historiefaget er (mestendels) en deskriptiv og forklarende videnskab og kan derfor kun bruges til rent oplysende formål (Kr. Erslev \& H. Kirchhoff).

3. historieforskning forudsætter også en moralsk-politisk stillingtagen til de udforskede emner og kan derfor ligeledes bruges til at påvirke folks stillingtagen til moralsk-politiske stridsspørgsmål (C. Banke).

Få eller ingen danske faghistorikere vil i dag forsvare den første position i sin klassiske form - altså den, som Munch gik ind for, og som bl.a. historiematerialister søgte at normsætte i 1960erne og 1970erne (Schaff 
1977). Men Habermas har i Erkenntnis und Interesse (1968) argumenteret for en mere plausibel variant af en sådan position. Der findes - hævder han de videnskaber, der arbejder med et præskriptivt eller handlingsvejledende sigte for øje. Hans yndlingseksempel er psykoanalysen, og der kan godt argumenteres for, at når historikere behandler samfundshistoriske patologier som fx folkedrab, vil det (som oftest/altid) ske med et præskriptivt eller handlingsvejledende mål for øje.

Den anden position er den, der har været fremherskende i dansk faghistorie, og få faghistorikere vil være uenig i, at som al anden videnskab bør historiefaget kunne fremlægge nøgterne og afbalancerede analyser af de sagforhold, der udforskes. Det betyder ikke, at der altid vil være enighed om, hvordan sagen stiller sig, men offentligheden har krav på at få en velbegrundet redegørelse for, hvad historieforskere er enige og uenige om, og hvorfor de er uenige.

Når det drejer sig om historieforskning, gør en anden vanskelighed sig imidlertid gældende. Der er ganske vist muligt at skrive identitetsneutral historie - dvs. historier, hvor få eller ingen identitetsaktier er i spil. Men det er ikke den slags historieforskning, der påkalder sig større interesse i det omgivne samfund. En del af den foreliggende historieforskning vedrører identitetsfølsomme eller ligefrem ømfindtlige emner; dansk flygtningepolitik før og under besættelsen udgør et oplagt eksempel.

Det er naivt at antage, at faghistorikere i praksis vil kunne holde sig til en strengt oplysende historiebrug i sådanne sammenhænge. Det er nemlig ved hjælp af fortidsfortolkninger, at erindrings- og handlefællesskaber opretholdes og bearbejdes (Jensen 2008), og faghistorikere vil med eller mod deres vilje - blive inddraget i de aktuelle identitetspolitiske interesse- og konfliktfelter. Og i så fald vil det være meget bedre, hvis de træder i karakter og åbent positionerer sig i forhold til de historiepolitiske emner, der behandles (Jensen 2009a).

Dermed har vi nærmet os den tredje position. Der er i dag behov for at få etableret en refleksiv og selvkritisk faglighed, der vedgår, at det i praksis ofte ikke vil være muligt at udmønte en værdineutral historieforskning og historieskrivning. Men i så fald vil det være vigtigt, at faghistorikere formår at skrive historie med afsæt $\mathrm{i}$ en dobbeltrolle - nemlig det at kunne agere på samme tid som både samvittighedsfulde fagfolk og demokratiske medborgere. I et demokrati er der intet fordækt eller problematisk i at ville påvirke ens medborgeres opfattelser, blot det sker på en demokratisk legitim måde. Det vil kun blive problematisk, såfremt fagfolk ikke respekterer 
deres medborgeres ret til at træffe deres egen værdi- og identitetsvalg (Jensen 2005). En af de afgørende faglige udfordringer består derfor i dag $i$ at kunne skrive historie med afsæt i en afsenderposition som både fagfolk og medborgere (Warring 2000).

\section{Litteraturliste}

Augstein, Rudolf (1987): Historikerstreit, München: Piper.

Banke, Cecilie (2005): Demokratiets skyggeside. Flygtningen og menneskerettigheder i Danmark for Holocaust, Odense: Syddansk Universitetsforlag.

Blüdnikow, Bent (2005): "Vi skal hele tiden genfortolke historien", Berlingske Tidende, 24.04.2005.

Bonde, Christen (2008): "Flygtningepolitik under lup", Historie, p.114-120.

Engelstoft, Povl (1943): "Historie" i Svend Dahl (red.), Danmarks Kultur ved Aar 1940, bd. 7, København: Det Danske Forlag, p.155-165.

Erslev, Kristian (1937): Historiske Afhandlinger, bd. 2, København: Hagerups Forlag.

Fischer, Torben \& Lorenz, Matthias N. (2007): Lexikon der ,Vergangenbeitsbewältigung' in Deutschland, Bielefeld: Transcript.

Fulbrook, Mary (1999): German National Identity after the Holocaust, Cambridge: Polity Press.

Habermas, Jürgen (1968): Erkenntnis und Interesse, Frankfurt: Suhrkamp.

Jensen, Bernard Eric (2005): "Om at føre identitetspolitik i et demokrati - en problemudredning" i Korsgaard, Ove (red.), Medborgerskab, identitet og demokratisk dannelse, København: Danmarks Pædagogiske Universitetsforlag, p.65-86.

Jensen, Bernard Eric (2008): "Danmarkshistorier som identitetspolitik", Historie, bd. 2008, p.150-156.

Jensen, Bernard Eric (2009a): "Identitetshistorie" \& "Identitetspolitik" i Gads Historieleksikon, 4.udg., København: Gad, p.267-268.

Jensen, Bernard Eric (2009b): "Et fag i spild med sig selv: antikvarisk eller pragmatisk historiebrug?", Noter om historie og undervisning, nr. 182, p.31-42.

Jensen, Bernard Eric (2010): Hvad er historie, København: Akademisk Forlag.

Jensen, Helle Strandgaard \& Warring, Anette (2006): "Dansk flygtningepolitik i 1930erne", 1066, bd. 36, nr. 3, p.37-40.

Kirchhoff, Hans (2003a): "Når selvrespekten skal rettes op", (kronik), Information, 15.10.2003.

Kirchhoff, Hans (2003b): "Fogh dæmoniserer historien", (kronik), Information, 16.10.2003.

Kirchhoff, Hans (2005a): "Forsvar for historikerne", (kronik), Information, 26.05.2005.

Kirchhoff, Hans (2005b): Et menneske uden pas er ikke noget menneske. Danmark, i den internationale fygtningepolitik. 1933-1939, Odense: Syddansk Universitetsforlag. 
Manniche, Jens Chr. (1981): Den radikale historikertradition, Aarhus: Universitetsforlaget.

Munch, P. (1907): "Studentersamfundets Fremtidsopgaver" i Studentersamfundet gennem Fem og Tyve Aar. Jubilaumsskrift, København: Gyldendal, p.13-30.

Rasmussen, Anders Fogh (2003): "Det drejer sig om at turde handle" i Fred i Fribed $i$ anledning af 60-airet for 29. angust 1943 (= Skoleavis udgivet af Folk \& Forsvar og Frihedskampens Veteraner).

Rasmussen, Anders Fogh (2005): "Samarbejdspolitikken sikrede ikke demokratiet", (kronik), Jyllands-Posten, 04.05.2005.

Rasmussen, Anita Brask (2005): 'Du valgte selv at trykke på aftrækkeren”, Information, 06.04.2005.

Scharff, Adam (1977, [1970]): Historie og sandhed, Grenå: GMT.

Sjøqvist, Viggo (1976): Peter Munch. Manden Politikeren Historikeren, København: Gyldendal.

Vilhjálmsson, Vilhjálmur Örn (2000): "Den største myte", (kronik), Berlingske Tidende, 06.02.2000.

Warring, Anette (2000): 'Historieformidling - i et demokratisk perspektiv", i B.E. Jensen (red.), At bruge bistorie, København: Roskilde Universitetsforlag, p.178-194.

Wolfrum, Edgar (1999): Geschichtspolitik in der Bundesrepublik Deutschland, Darmstadt: Wissenschaftliche Buchgesellschaft. 